\title{
Physiological condition in Magellanic Penguins: Does it matter if you have to walk a long way to your nest?
}

\author{
Brian G. Walker \\ Fairfield University, bwalker@fairfield.edu \\ P. Dee Boersma
}

John C. Wingfield

Follow this and additional works at: https://digitalcommons.fairfield.edu/biology-facultypubs Copyright 2004 University of California Press for Cooper Ornithological Society

\section{Peer Reviewed}

\section{Repository Citation}

Walker, Brian G.; Boersma, P. Dee; and Wingfield, John C., "Physiological condition in Magellanic Penguins: Does it matter if you have to walk a long way to your nest?" (2004). Biology Faculty Publications. 25. https://digitalcommons.fairfield.edu/biology-facultypubs/25

\section{Published Citation}

Walker, BG, PD Boersma, and JC Wingfield. 2004. Physiological condition in Magellanic Penguins: Does it matter if you have to walk a long way to your nest? Condor 106 (3):696-701.

This item has been accepted for inclusion in DigitalCommons@Fairfield by an authorized administrator of DigitalCommons@Fairfield. It is brought to you by DigitalCommons@Fairfield with permission from the rightsholder(s) and is protected by copyright and/or related rights. You are free to use this item in any way that is permitted by the copyright and related rights legislation that applies to your use. For other uses, you need to obtain permission from the rights-holder(s) directly, unless additional rights are indicated by a Creative Commons license in the record and/or on the work itself. For more information, please contact digitalcommons@fairfield.edu. 


\title{
PHYSIOLOGICAI CONDITION IN MAGELLANIC PENGUINS: DOES IT MATTER IF YOU HAVE TO WALK A LONG WAY TO YOUR NEST?
}

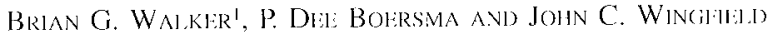 \\ Department of Biology, University of Washington, BOx 35/800, Seatle, WA 98195
}

\begin{abstract}
Colony edges, as opposed to interiors, are often considered less advantageous nesting places in colonial species. For temperate-breeding penguins, inland colony edges should be less desirable than other edges, as there are added costs of walking farther in land, and ambient temperatures are higher. During setflement and incubation, we compared body condition and baseline and stress-induced levels of the hormone corticosterone in male Magellanic Penguins (Spheniscas magellanicus) nesting on the sea edge of a colony with those nesting on the inland edge, $>800 \mathrm{~m}$ from shore. Body condition in both groups was significantly lower during settlement than during incubation, but was similar in both groups within breeding stages. Corticosterone levels were similar between breeding slages and for groups within each breeding stage. While body condition can vary over time, penguins appear to be well bulfered to physiological extremes, as they do not show modification of corticosterone levels with variations in nesting conditions.
\end{abstract}

Key words: corticosterone, energetic costs of nesting, Magellanic Penguin, penguin physiology, Spheniscus magellanicus.

Condiciones Fisiológicas en el Pingüino Spheniscus magellanicus: ¿Tiene Importancia Caminar una Larga Distancia al Nido?

Resumen. En especies coloniales, los bordes de la colonia son gencralmente considerados como lugares menos ventajosos para el cstablecimiento de nidos. Para los pingüinos que crían en climas templados, los bordes de las colonias orientados tierra adentro deben ser menos deseables que otros bordes, ya que se suman los costos adicionales de caminar una distancia mayor desde la orilla y debido a que las temperaturas ambientes allí son más elevadas. Durante el establecimiento y la incubación, comparamos las condiciones corporales y los niveles de referencia e inducidos por estrés de lat hormona corticosterona en los machos de Spheniscus magellanicus que anidaban en el borde de la colonia adyacente al mar con los que anidaban sobre el borde que mira hacia el interior, a más de $800 \mathrm{~m}$

Manuscript received 14 October 2003; accepted 16 March 2004.

Present address: A7. Biodesign Institute, Arizona State University, P.O. Box 870404, Tempe AZ 852870404. E-mail: brian.g. walker@asu.edu desde la orillá. La condición corporal en los dos grupos fue significantemente monor durante el establecimiento que durante la incubación. pero lue similar en los dos grupos durante las ctapas de crianza. Los niveles de corticosterona fueron similares para ambas elapas de crianza y para los dos grupos durante cada clapa de crianza. Aunque la condición corporal puede valtiar en el tiempo, los pingüinos parecen amortiguar bien los extremos fisiológicos, ya que no muestran modificación de los niveles de corticosterona con las variaciones en las condiciones de nidificación.

Animals sulfer physiological consequenees for living in marginal habitats (Wingficld 1994). For example, individuals in more extreme environments such as deserts or poor wintering habitat may experience elevated baseline levels of glucocorticosteroids (in birds, corticosterone; Winglield el al. 1992, Marra and Holberton 1998). These elevated bascline levels of corticosterone are important for the maintenance of homeostatic energy balance in suboptimal conditions (Dallman el al. 1993). Basseline levels of corticosterone also fluctuate on predictable (e.g., daily) cycles (Breuner et al. 1999) or during life-history changes such ats migration or molt (Ramenofsky et al. 1995, Romero et al. 1997, Deviche et al. 2000). In addition to its bascline, homeostatic functions, corticosterone also increases rapidly in times of acute, unexpected stress, and mobilizes the additional energy needed to survive during unexpected perturbations (Winglield and Ramenofsky 1999, Sapolsky et al. 2000). Furthermore, physiological condition of individuals also can affect corticosterone levels. Indeed, birds in very poor body condition (e.g., after extensive lasts or very poor cat loric diets; Cherel, Robin, Walch, et al. 1988, Hood et al. 1998, Kitaysky et al. 1999) have higher corticosterone liters. Importantly, however, it appears that corticosterone and body condition do not relate in a linear fashion, and it appears that only when animals are in extremely poor condition do hormone levels start to rise (c.g., PHASE III, Cherel, Robin, and LeMaho 1988).

For colony-nesting birds, much altention has fo cused on nest-site selection and the reproductive bencfits gained by position in a colony (Acbischer and Coulson 1990, Brunton 1997, Massaro el al. 2001). However, little attention has locused on the physiological costs sulfered by individuals nesting in different locations in colonies. Nests on colony edges are generally of lower quality, and parents nesting there have 
lower reproductive success (Tenaza 1971, Kharitonov and Siegel-Causey 1988, Regehr et at. 1998). For flying birds, regardless of colony size, the costs of returning to edge nests are likely similar among individuals. In contrast, penguins must walk from the ocean to their nests. Walking is energetically costly for penguins (Pinshow et al. 1977, Dewasmes et al. 1980, Griffin and Kram 2000); therefore birds nesting on the inland cdge must expend more encrgy to reach their nest sites. Additionally, for temperate-breeding penguin species, inland-nesting birds may suffer additional physiological costs due to increased ambient temperatures far from the sea. Indeed, in temperate-breeding species such as African Penguins (Spheniscts demersus; Frost et al. 1976), Galápagos Penguins (Spheniscus mendiculus; Bocrsma 1974), and Magellanic Penguins (Spheniscus magellanicus; Stokes and Boersma 2000), adults and chicks often overheat and die.

Magellanic Penguins live along the southern Atlantic and Pacific coasts of South America (Williams 1995). The largest colony of this species is located at Punta Tombo, Argentina (Gandini et al. 1996), where birds nest from within meters of the high-tide line to $1 \mathrm{~km}$ inland (Boswall and MacIver 1975). During settlement, male penguins establish and defend nest sites, and although they may return to the ocean to drink, they fast for upwards of 30-40 days (Yorio and Boersma 1994, Hood et al. 1998). After females lay eggs, males go to sea to feed and return 15-30 days later to relieve their mate and continue incubating the eggs (Yorio and Boersma 1994). At Punta Tombo, penguins nesting inland have lower reproductive success than penguins nesting in other areas (Gochfeld 1980, Frere et al. 1992, Stokes and Boersma 1998), partly because of the increased temperatures of inland habitat (Stokes and Boersma 1998). However, predation pressure does not appear to contribute to the lower reproductive success inland, as predation pressure is the highest in the densest areas of the colony (Stokes and Boersma 2000). Despite the potential benefits of lower nest densities and decreased fighting for penguins nesting at the colony's inland edge (Stokes and Boersma 2000), males have to walk farther; are subjected to higher ambient temperatures, and likely have a lower probability of attracting a mate. Indeed, nest quality and reproductive success are higher in areas of the colony wherc penguins can build thermally insulated burrows, unlike the nests on the edges of the colony, which typically are located below bushes (Stokes and Boersma 1991). This suite of negative characteristics of inland-edge nests suggests that the physiologic costs of nesting inland may be greater for penguins choosing to settle there.

We examined the differences in body condition and corticosterone levels between Magellanic Penguins that were nesting on the sea edge or inland edge of the colony at Punta Tombo. We expected both groups would be in poorer body condition and have higher corticosterone levels during settlement than upon return from their preincubation foraging trip. During the energetically demanding settlement stage, we expected inland-edge penguins to have higher plasma corticosterone and be in poorer body condition than shore- edge birds, due to the added negative costs of nesting inland. However, we expected both shore-edge and inland-edge penguins to have similar body condition and hormone levels just after returning from the preincubation foraging trip, when encrgetic losses from the previous settlement period hat been fully replenished.

\section{METHODS}

We compared the physiological condition and circulating corticosterone levels in Magellanic Penguins nesting within $20 \mathrm{~m}$ of the colony edge nearest the water ("shore edge") to those nesting on the landward side ("inland edge") of the Punta Tombo penguin colony, Chubut, Argentina $\left(44^{\circ} 02^{\prime} \mathrm{S}, 62^{\circ} 11^{\prime} \mathrm{W}\right)$ during the breeding season of 1999-2000. Inland nests were a minimum of $800 \mathrm{~m}$ from the sea, as measured by walking a straight line from the nest to the high-tide line. We used only males in this study to control for differences between the sexes in chronology associated with foraging and incubating schedules early in the breeding season. We sampled penguins in both areas during two breeding stages: (1) settlement, when males were fasting in their nest, waiting for females to return to the colony; and (2) incubation, when males had just returned from the long, preincubation foraging trip. We sampled 10 penguins in each area during each breeding stage. No penguin was sampled twice. During settlement, we captured lone males by searching nests along the shore and inland edges of the colony. These males were chosen 2-3 weeks after the initial return of males to the Punta Tombo colony in 1999. During incubation, we selected nests with females on eggs, checked them daily, and captured the males on the day they returned from foraging to relieve the female.

We took a blood sample within 3 min of capture to measure levels of corticosterone in plasma. As circulating corticosterone does not increase significantly until 3 min after disturbance in most animals (Wingfield et al. 1982), this sample represented the baseline or constituent level of corticosterone in the plasma, prior to the capture stress. Birds were held for $30 \mathrm{~min}$, and sequential blood samples collected at 10 and $30 \mathrm{~min}$ after initial disturbance, to measure increases in corticosterone in response to the capture. We collected blood samples $(75-150 \mu \mathrm{L})$ into heparinized microcapillary tubes after puncture of the interdigitary (footweb) vein. Samples were held on ice in the field and were later centrifuged to separate plasma. Plasma samples were subsequently frozen at $-10^{\circ} \mathrm{C}$ until transferred to the laboratory for analysis. We measured corticosterone in plasma samples following a modified direct radioimmunoassay format (Wingfield and Farner 1975), without chromatography, as described in Wingficld et al. (1992).

During restraint, we weighed each bird with a spring balance (to the nearest $100 \mathrm{~g}$ ) and measured bill length, bill depth, flipper length, and foot length using a dial calipers (to the nearest $0.01 \mathrm{~cm}$ ) or ruler (to the nearest $0.1 \mathrm{~cm}$ ). Body size was calculated as 0.899 (bill length) +0.924 (bill depth) $+0.867($ flipper length $)+$ 0.907 (foot length). Coefficients were component scores from a principal components analysis of standardized morphological measurements for this species (from Hood et al. 1998). Body condition was deter- 


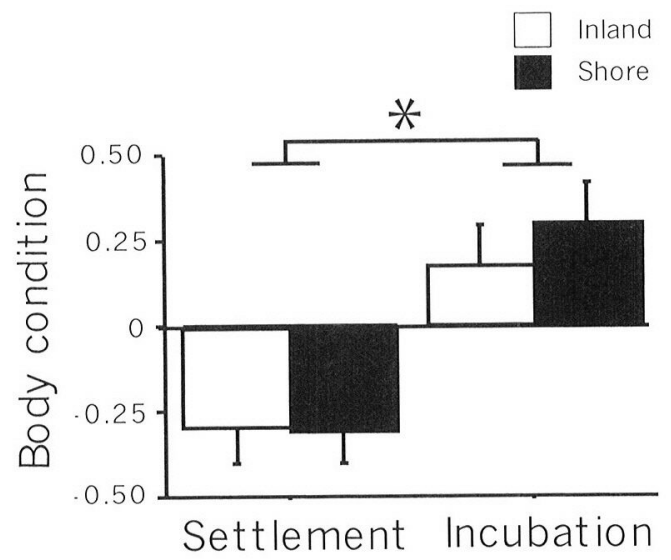

FIGURE 1. Body condition (mean $\pm \mathrm{SE}$ ) of male Magellanic Penguins nesting on the inland edge and shore edge of a colony at Punta Tombo, Argentina, during two stages of the breeding season (settlement and incubation). There were no differences in body condition within breeding stages, but body condition for penguins was significantly lower during settlement. Body condition is an index derived from principal components analysis of four body measurements. Sample size $=10$ individuals for each area during each breeding stage. $* P<0.05$ from a two-factor ANOVA.

mined using the residuals of a regression between body size and mass (Hood et al. 1998). Negative residuals indicated a bird was in poor condition for its size, and positive rcsiduals indicated a bird was in good body condition.

\section{STATISTICAI, ANALYSIS}

We tested for differences in body size and baseline levels of corticosterone in penguins between breeding stages and different edges of the colony using a twoway ANOVA with breeding stage and location as lixed factors. To guantily how penguin corticosterone levels responded to the stress scrics protocol, we integrated the corticosterone data from baseline to $30 \mathrm{~min}$ using the arithmetic trapezoidal rule (i.e., we calculated the area under the curve; Breuner et al. 1999, Picard-Hagen et al. 2001). The integrated value provided a measure of total corticosterone secreted during the capturestress challenge, while encompassing the preexisting levels of circulating corticosterone prior to disturbance. Integrated corticosterone levels were compared with two-way ANOVA and Fisher's PLSD. We logtransformed corticostcrone data prior to analysis to satisfy assumptions of non-normality and heterogencity of variance. We used $\alpha=0.05$ and the StatView computer program (SAS Institute 1998) for all statistical analyses.

\section{RESULTS}

Males in both shore-edge and inland-cdge nests were in better body condition when they returned from their preincubation foraging trip than they were during settlement $\left(F_{136}=24.6 ; P<0.001\right.$; Fig. 1). Body condition was similar for sca-edge and inland-edge nesters

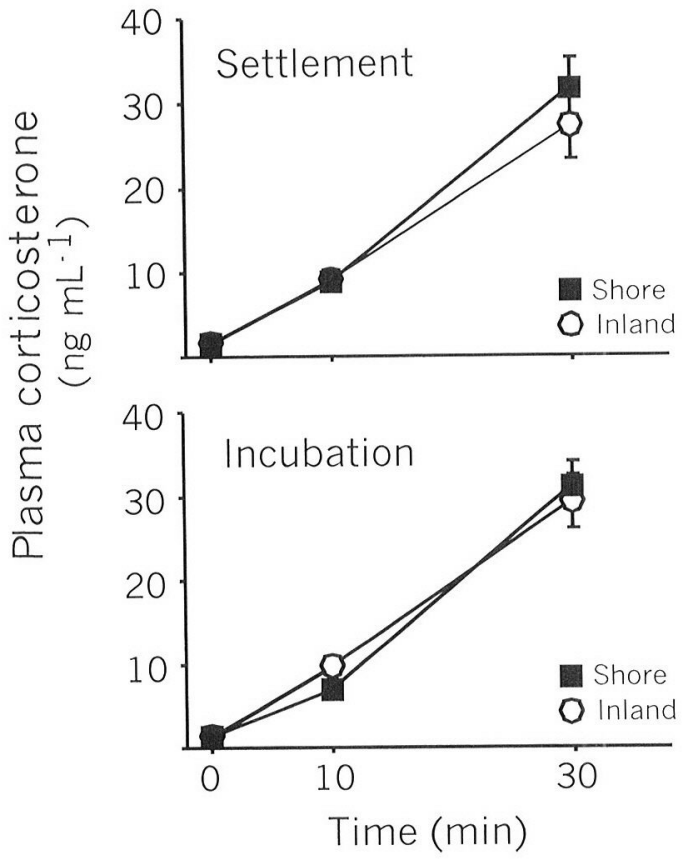

FIGURE 2. Patterns of corticosterone increase for Magellanic Penguin males subjected to a capture stress protocol. Penguins nested on either the inland edge or shore edge of the colony at Punta Tombo, Argentina, and were sampled during two stages (settlement and incubation) of the 1999-2000 breeding season.

within each breeding stage $\left(F_{1.36}=0.2 ; P=0.63 ;\right.$ Fig. 1). There was no interaction between treatments $\left(F_{1,36}\right.$ $=0.4 ; P=0.51$ ).

Baseline corticosterone levels were similar between settlement and incubation stages $\left(F_{1.36}=2.8 ; P=0.11\right.$; Fig. 2), and shore-edge and inland-edge penguins had similar baseline corticosterone levels $\left(F_{1.3 ;}<0.1 ; P=\right.$ 0.91; Fig. 2). There was no interaction between treatments $\left(F_{1.36}=0.8, P=0.38\right)$. The amount of corticosterone secreted during capture and handling (i.e., integrated corticosterone) was similar between breeding stages $\left(F_{1.36}<0.1 ; P=0.91\right.$; Fig. 2$)$ and areas $\left(F_{136}=0.1, P=0.75\right.$; Fig. 2$)$. There was no interaction between location and breeding stage $\left(F_{1.36}=0.6\right.$, $P=0.46)$. Finally, there was no significint correlation between body condition and cither baseline corticosterone or integrated corticosterone for shore-edge or inland-edge penguins during either breeding stage (Table $1)$.

\section{DISCUSSION}

As predicted, body condition was lower in setuling penguins compared to birds returning from foraging. Settling males were fasting while wating for females to return to the colony, whereas males returning from the preincubation foraging trip had replenished energy stores in order to incubate eggs. These dilferences in body condition between the two breeding stages, how- 
TABLE 1. There were no correlations between body condition and baseline or integrated levels of corticosterone for male Magellanic Penguins living inland or along the shore at a colony at Punta Tombo, Argentina. Ten male penguins were measured at each location and each breeding stage; no penguins were measured twice.

\begin{tabular}{lccrrr}
\hline \hline & \multicolumn{2}{c}{$\begin{array}{c}\text { Baseline } \\
\text { corticosterone }\end{array}$} & & \multicolumn{2}{c}{$\begin{array}{c}\text { Integrated } \\
\text { corticosterone }\end{array}$} \\
\cline { 2 - 3 } $\begin{array}{l}\text { Location } \\
\text { Breeding stage }\end{array}$ & $r^{2}$ & $P$ & & $r^{2}$ & $P$ \\
\hline Inland & & & & & \\
$\quad$ Settlement & 0.04 & 0.60 & & $<0.001$ & 0.97 \\
$\quad$ Incubation & 0.15 & 0.27 & & 0.001 & 0.94 \\
Shore & & & & & \\
$\quad$ Settlement & $<0.001$ & 0.97 & & 0.001 & 0.92 \\
$\quad$ Incubation & 0.44 & 0.56 & & 0.004 & 0.86 \\
\hline
\end{tabular}

ever, were not reflected in the baseline or stress-induced levels of plasma corticosterone.

While males during settlement had been ashore fasting long enough for their overall body condition to worsen significantly, plasma corticosterone levels were the same as in incubating birds. Furthermore, across all animals, there was no correlation between body condition and plasma corticosterone levels. Hood et al. (1998) showed that for Magellanic Penguins, baseline corticosterone did not increase in fasting males or females up to 14 days after food deprivation, but did increase in females fasting for over 19 days. Similarly, for both sexes, stress-induced corticosterone (after 25 min of capture) showed only a slight increasing trend as the fast progressed (Hood et al. 1998). It therefore appears that Magellanic Penguins do not incorporate the energetic benefits of increased corticosterone (e.g., increased energy mobilization, Wingfield 1994) until they are in extremely poor condition. Thus, the male Magellanic Penguins that we sampled during the settlement period had apparently not yet spent enough time ashore to reach an extreme level of physiological compromise that would elicit changes in corticosterone profiles. That significant increases in corticosterone levels do not occur until severe physiological compromise is not surprising. Both King Penguins (Aptenodytes patagonicus) and Emperor Penguins (Aptenodytes forsteri) withstand periods of extended fasting while raising young (Cherel, Robin, and LeMaho 1988, Cherel, Robin, Walch, et al. 1988, Cherel et al. 1994), with corticosterone levels only increasing very late (35-40 days) into the fast (Cherel, Robin, Walch, et al. 1988). Indeed, it appears that other physiological cofactors (e.g., protein breakdown as measured by uric acid, Jenni et al. 2000) directly relate to how and when glucocorticosteroid levels change in physiologically compromised individuals. Recently, McEwen and Wingfield (2003) proposed that it is not until animals reach a point of "allostatic overload," that is, until they surpass their normal capacity to physiologically adapt to perturbations, that certain corrective mechanisms such as corticosterone lcvels will change.
We found no differences in body condition between shore-edge and inland-edge nesting penguins, nor were baseline corticostcrone or patterns of corticosterone change different. We expected these similarities between shore-edge and inland-edge males for birds returning from foraging. Both groups would be equally likely to return energetically prepared for incubation. However, we did not expect to find that settling shoreedge and inland-edge males also had similar body condition and corticosterone levels. Costs during the long period of settlement for inland-edge nesters (i.e., higher heat index, higher transit costs, lower likelihood of attracting mates) were predicted to cause an increased energetic demand as compared to birds nesting directly along the shoreline. However, for shore-edge nesting penguins, factors such as increased penguin density and the concomitant increases in fighting at the nest site (Stokes and Boersma 2000) may decrease the physiologic benefits of nesting close to the ocean.

The most notable difference between shore-edge and inland-edge nest sites was the added minimum of 800 $m$ that inland-edge penguins walked to get to their nests. We hypothesized that walking this distance would be cnergetically costly for a penguin nesting inland. However, we found that corticosterone levels and body condition were similar for both groups during both periods. Various authors have shown that the waddling of penguins is energetically demanding as compared to the gait of other birds (Pinshow et al. 1977, Griffin and Kram 2000). Such costs may be primarily due to the evolutionary constraints imposed on flightless species adapted to both aquatic and terrestrial environments (Fish and Baudinette 1999, Fish et al. 2001 ). Our data suggest that walking $>800 \mathrm{~m}$ to inland-edge nests must be a minor physiological cost. However, during both the periods we chose to examine, the males had made only made one recent trip to the nest. Perhaps a more appropriate period to measure any added physiological cost of nesting on the inland edge of the colony would be during chick rearing. During this period, ambient temperatures are higher (up to $35^{\circ} \mathrm{C}$, Stokes and Boersma 1998), and adults make multiple trips back and forth to feed young. Thus, adults experience increased thermal constraints, higher energetic output from multiple transits, and an increased energetic demand from their chicks. None of these were present during either the settlement or incubation periods that we examined.

To our knowledge, our study is the first to examine whether nesting in different areas of a colony affects body condition and corticosterone levels in birds. Other authors have used corticosterone assessment to examine the energetic consequences of nesting in different environments (e.g., desert vs. moderate climates, Wingfield et al. 1992) or the effects of human disturbances such as recreational vehicles (Creel et al. 2002) or tourism (Romero and Wikelski 2002, Walker 2003). That both body condition and corticosterone levels were similar between shore- and inland-nesting birds suggests that Magellanic Penguins are relatively robust to variations in nesting conditions within their breeding colony. Previous studies quantifying the costs of nesting in different areas of the colony focused primarily on differences in reproductive success (Parrish 
1995. Massaro ed al. 2001). However, measuring how an individual's physiology may be compromised during reproduction is also important. While reproductive output may be equal within a season, animals with a higher energetic output may sulfer subsequent negative consequences such as lowered luture reproductive success or even decreased longevity (Cody 1966, Drent and Dakan 1980). Such potential consequences are not measurable by assessment of within-season reproductive output alone.

The Institutional Animal Care and Use Committee, University of Washington, approved all handling and sampling procedures. We thank A. N.VanBuren and A. Nichatus for help with fieldwork and O. Fererria, G. Harris, and P. Harris for logistical support while in Argentina. L. Erckmann helped with the corticosterone assay. S. Busch, M. Landys, and M. Ramenofsky provided helpful comments on early drafts of the manuscript. J. Wallbrecht translated the abstract into Spanish. This work was supported by the Wildilife Conservation Sociely, New York, through an agreement with the Organismo del Turismo, Chubut, Argentina and grants from the American Ornithologists" Union and the Muscum of Natural History, New York, to BGW.

\section{LITERATURE (CITEI)}

ArbIsCH:R, M. J., AND J. C. Coulson. 1990. Survival of the Kitliwake in relation to sex, year, breeding experience and position in the colony. Journal of Animal Ecology 59:1063-1071.

Bol:Rsma, P. D. 1974. The Galápagos Penguin: a study of adaptations for life in an unpredictable environment. Ph.D. dissertation, Ohio State University, Columbus, $\mathrm{OH}$.

Boswal., J., ANI D. MAc IVI:R. 1975. The Magellanic Penguin Spheniscus magellanicus, p. 271-305. In B. Stonchouse |El|).|, The biology of penguins. Macmillan. I ondon.

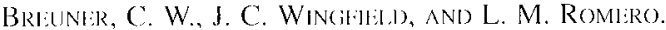
1999. Diel thythms of basal and stress-induced corticosterone in a wild, seasonal vertebrate, Gambel's White-crowned Sparrow. Journal of Experimental 7oology $284: 334-342$.

Bruntron, D. H. 1997. Impacts of predators: center nests are less successful than edge nests in a large nesting colony of Lealst Terns. Condor 99:372380

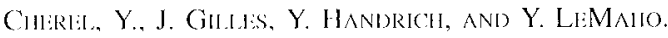
1994. Nutrient reserve dynamics and energetics during long-term lasting in the King Penguin (Aprenodves paragonicus). Jounal of \%oology, Iondon $234: I-12$.

CIIIRIII, Y., J.-P. RobIN, ANI) Y. L LiMAIIO. 1988. Physiology and biochemistry of long-term fasting in birds. Canadian Journal of Zoology 60:159-166.

Cherri, Y., J.-P. Rolin, O. Walch, H. Karmann, P. Niatollitilo, AND, Y. LI:MAllo. 1988. Fasting in King Penguin I. Hormonal and metabolic changes during breeding. American Journal of Physiology 2.54:R170-R177.

Colsy. M. L. 1966. A general theory of elutch size. Evolution 20:174-184.
Crlili, S., J. E. Fox, A. Haridy, J. Sands, B. Garrott, AN1 R. O. PIITIRSON. 2002. Snowmobile activity and glucocorticoid stress responses in wolves and ekk. Conservation Biology 16:809-814.

DALLMAN, M. F., A. M. STRACK, S. F. AKANA, M. J. BRADBUIRY, E. S. HANSON, K. A. SCRIBN]IR, ANI M. Smith. 1993. Feast and famine: critical role of glucocorticoids with insulin in daily energy flow. Frontiers in Neuroendocrinology 14:303-347.

Deviche, P., J. C. Wingiletid, and P. J. Sharp. 2000. Year-class differences in the reproductive system, plasma prolactin and corticosterone concentrations, and onset of prebasic molt in male Darkeyed Juncos (Junco hyemalis) during the breeding period. General and Comparative Endocrinology $118: 425-435$

Dinasmis, G., Y. LliMario, A. Colrnis, And R. GrosCol.As. 1980. Resting metabolic rate and cost of locomotion in long-term fasting Fmperor Penguins. Journal of Applied Physiology 49:888-896.

DRENT, R. H., AND S. DAAN. 1980. The prudent parent: energetic adjustments in avian breeding. Ardea 68:225-252.

FISH, F. E., AND R. V. BALDINETIT: 1999. Encrgetics of locomotion by the Australian water rat (Hydromys chrysogerster): a comparison of swimming and running in a semi-acualic mammal. Journal of Experimental Biology 202:35.3-363.

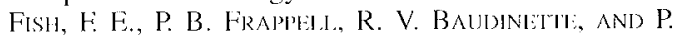
M. MACFARI ANE. 2001. Energetics of terrestrial locomotion of the platypus Ornithorhynchus anatimus. Journal of Experimental Biology 204:797803.

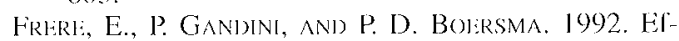
feets of nest type and location on reproductive success of the Magellanic Penguin Spheniscus magellanicus. Marine Ornithology 20: I-6.

Frost, P. G. H., W. R. SHGirilid, AN] A. E. BurcitR 1976. Behavioural adaptations of the Jackass Penguin, Spheniscus demersus to al hot, arid environment. Journal of Zoology, london 179:165-187.

Gandini, P. A., E. Frisi:, anis P. D. Botrosma. 1996. Status and conservation of Magellanic Penguins (Spheniscus magellanicus) in Patagonia, Argentinal. Bird Conservation International 6:307-316.

Gochtitid, M. 1980. Timing of breeding and chick mortality in central and peripheral nests of $\mathrm{Ma}^{-}$ gellanic Penguins. Auk 97:191-193.

GRIFirin, T. M., AND R. KRAM, 2000. Penguin waddling is not wasteful. Nature 408:929.

HOOI), L. C., P. D. BOIRSMA, NND J. C. WINGIIIID. 1998. The adrenocortical response to stress in incubating Magellanic Penguins (Sphenisczts magellanicus). Auk 115:76-84.

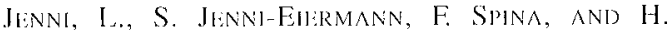
ScIIWABI. 2000. Regulation of protein breakdown and adrenocortical response to stress in birds during migratory flight. American Journal of Physiology Regulatory Integrative and Comparative Physiology 278:R1182-R1189.

Kharironov, S. P., anis D. Shicia Causizy, 1988. Colony formation in scabirds. Current Ornithology 5 : $223-272$. 
Kitaysky, A. S., J. C. Winghilid, anid J. F. Piatt 1999. Dynamics of food availability, body condition and physiological stress response in breeding Black-legged Kittiwakes. Functional Ecology 13:577-584.

Marra, P. P., and R. L. Hol blirton. 1998. Corticosterone levels as indicators of habilat quality: effects of habitat segregation in a migratory bird during the non-breeding season. Oecologia 1 16:284-292.

Massaro, M., J. W. Chardine, and I. L. Jonis. 2001. Relationships between Black-legged Kittiwake nest-site characteristics and susceptibility to predation by large gulls. Condor 103:793-801.

MCEWEN, B. S., ANIJ J. C. WINGIJEID. 2003. The concept of allostasis in biology and biomedicine. Hormones and Bchavior 43:2-15.

PARRISH, J. K. 1995. Influence of group size and habitat lype on reproduclive success in Common Murres (Uria aclge). Auk 112:390-401.

Picard-Haglen, N., V. GAyrard, M. Alvinerie, H. Smirers, R. Ricou, A. Bousquel-Melou, and P. L. ToutAin. 2001. A nonlabeled method to evaluate cortisol production rate by modeling plasma CBG-free cortisol disposition. American Journal of Physiology Endocrinology and Mebabolism 281:E946-E956.

Pinshow, B., M. A. Feidnk, and K. Schmidt-Nielsen. 1977. Terrestrial locomotion in penguins: it costs more to waddle. Science 195:592-594.

Ramenofiky, M., T. Pilirsma, nni J. Jukema. 1995. Plasma corticosterone in Bar-tailed Godwits at a major stop-over site during spring migration. Condor 97:580-585.

Reghilr, H. M., M. S. Romway, and W. A. MonthVECCIII. 1998. Antipredator benefits of nest-site selection in Black-legged Kitttiwakes. Canadian Journal of Zoology 76:910-915.

ROMLRO, L. M., M. RAMlinOFSKY, AND J. C. WINGHIELD. 1997. Season and migration alters the corticostcrone responsc to capture and handling in an arctic migrant, the White-crowned Sparrow (Zonotrichia leucophrys gambelii). Comparative Biochemistry and Physiology Part C 116C:171-177.

Romero, L. M., ANIS M. WIKELSKi. 2002. Exposure to tourism reduces stress-induced corticostcrone levels in Galápagos marine iguanas. Biological Conservation 108:371-374.

SAPOlsky, R. M., L. M. Romero, nNI A. U. Minck. 2000 . How do glucocorticoids influence stress responses? Integrating permissive, suppressive, stimulatory, and preparative actions. Endocrine Reviews 21:55-89.

SAS Institute. 1998. Statvicw 5.0. SAS Institute, Inc., Cary, NC.

Stokes, D. L., ANI P. D. Bofrsma. 199l. Effects of substrate on the distribution of Magellanic Penguin (Spheniscus magellanicus) burrows. Auk 108:923-933.

Stokes, D. L., AnI P. D. Bolirsma. 1998. Nest-sito characteristics and reproductive success in Magellanic Penguins (Spheniscus magellomicus). Auk 115:34-49.

STOKES, D. L., AND P. D. BOFRSMA. 2000. Nesting density and reproductive success in a colonial seabird, the Magellanic Penguin. Ecology 81:2878-2891.

TrenazA, R. 1971. Behavior and nesting success relative to nest location in Adélie Penguins (Pygoscelis adeliae). Condor 73:81-92.

WAI.KER, B. G. 2003. Development and modification of the adrenocortical stress response in adult and chick Magellanic Penguins (Spheniscus magellanicus). Ph.D. dissertation, University of Washington, Scattle, WA.

Williams, T. D. 1995. The penguins. Oxlord University Press, Oxford, UK.

WINGFIEI.D, J. C. 1994. Modulation of the adrenocortical response to stress in birds, p. 520-528. In K. G. Davey, R. E. Peter and S. S. Tobe [Los.], Perspectives in comparative endocrinology. National Rescarch Council of Canada, Ottawa, ON, Canada.

Winglield, J. C., and D. S. Farner. 1975. The determination of five steroids in avian plasma by radioimmunoassay and competitive protein-binding. Steroids 26:311-327.

Wingfifld, J. C., And M. Raminofisky. 1999. Hormones and the behavioral ecology of stress, p. 1 51. In P. H. M. Balm |ED.|, Stress physiology in animals. Sheffield Academic Press Lid, Shelfield, UK.

WingField, J. C., J. P. Smith, ANd D. S. FARNer. 1982. Endocrine responses of White-crowned Sparrows to environmental stress. Condor 84:399-409.

WingFifid, J. C., C. M. VIIICK, ANI M. C. MoOri: 1992. Seasonal changes of the adrenocortical response to stress in birds of the Sonoran Desert. Journal of Experimental Zoology 264:419-428.

Yorio, P., AND P. D. BoERSMA. 1994. Causes of nest desertion during incubation in the Magellanic Penguin (Spheniscus magellanicus). Condor 96: 1076-1083. 